\section{Political geography II: Violence}

Progress in Human Geography 202I, Vol. 0(0) I-7

(C) The Author(s) 2021

Article reuse guidelines: sagepub.com/journals-permissions DOI: $10.1177 / 03091325211062187$ journals.sagepub.com/home/phg

\section{Jennifer Fluri}

@SAGE

\author{
Department of Geography, University of Colorado-Boulder, Boulder, CO, USA
}

\begin{abstract}
This report focuses on the diverse and multiple manifestations of political, state, and counter-state violence. Many of the examinations of political violence in this report highlight the continued need for disparate methodological and analytic lenses towards robust understandings of political violence across scales. Displacements and mobilities associated with flight from conflict are discussed in relation to the institutionalization of harm, trauma and containment through various state and supranational mechanisms of control. These mobilities include border crossings and associated violence against vulnerable populations seeking refuge. This is buttressed by discursive binary logics, such as us/them categorizations, which remain endemic to both structural and physical violence and foundational to right wing populism, jingoism, and other forms of political extremism. This report concludes by arguing the peace is not the opposite of war but rather its temporal substitute and partner in an assemblage of political and economic co-dependence.
\end{abstract}

\title{
Keywords
}

war, violence, geopolitics, mobility, displacement, refugees, nationalism

As the Taliban took control of the capital city, Kabul, Afghanistan on 15 August 2021, the US led a chaotic and partial evacuation of Afghan allies. The multiple forms of violence that occurred during and in the aftermath of this incomplete evacuation (and over the past 42 years of military occupation, civil conflict, brutal governance, and more military occupation in Afghanistan) exemplifies the many spaces of continual, consistent, and cyclical war and violent conflict. Military, paramilitary, and insurgent violence represents one form of violence, while other institutionalized and state mechanisms of slow or calculated assault occur, such as displacing or disrupting a population's access to resources. Violence has been a regular feature of geopolitics and political transitions. Although political violence takes many forms from direct assault to structural and institutionalized violence that prevent individual or collective access to space, security, or life sustaining resources.
Conducting empirical, qualitative, and ethnographic fieldwork in spaces of war or heightened political conflict has prompted several scholars to reflect on the importance of this work along with its inherent security, ethical, and methodological challenges, as discussed in a recent special issue in Geopolitics (Brigden and Hallett, 2021). This report focuses on multiple forms of violence by and against the state along with research focused on refugee mobility, which underscores the continued forms of insecurity and violence, experienced by migrants, who are simultaneously embroiled within a morass of multiple political and economic losses.

\section{Corresponding author:}

Jennifer Fluri, Department of Geography, University of Colorado-Boulder, Guggenheim 100, 260 UCB, Boulder, CO 80309, USA. jennifer.fluri@colorado.edu 
Recent political machinations within and across countries have been buttressed by the pandemic, which has also laid bare the slow and unrelenting structural violence associated with existing inequalities and unequal access to political participation or influence. Geographers' commentaries on the COVID-19 pandemic further highlight violent identity-based marginalization and dispossession along with gross economic inequalities, many of which have spurred political unrest in various countries. The pandemic offered an excuse for some states to justify extensive offshore quarantines of migrants, quarantines generated from white supremacists capitalism and masculinist and patriarchal conceptualization of power, and a dangerous conflation between individual autonomy with collective independent-rule (Baldacchino 2021; Bialasiewicz and Eckes, 2021; Simpson 2021). In other cases, state responses to the pandemic align with far right extremism and increased ethnonationalism (Mitropoulos 2021).

This report also focuses on the diverse and multiple manifestations of political, state, and counter-state violence, while highlighting the continued need for disparate methodological and analytic lenses necessary for a robust understanding of political violence across scales. Some political geographers analyze state or inter-state violence at a macro scale, while others center the local and the body as a crucial sites of analysis, or incorporate multi-scalar analyses. Displacements and mobilities associated with flight from conflict further elucidate migrant experience and the institutionalization of harm, trauma, and containment through various state and supranational mechanisms of control.

\section{Displacements}

In an effort to preserve life or remove oneself from widespread violence within one's home country, many individuals and groups seek refuge through mobility and resettlement. These displacements range from internal to external border crossings and multiple interfaces with criminal and legal barriers to safety and security. Fleeing from violence regularly results in various forms of displacement, dispossession, and insidious harm associated with social and political marginalization, continual mobility, and living in a liminal space between precariousness and protection.

Several scholars have centered refugee experiences to emphasize the assemblage of complexities, multiplicities of transiency, while attending to the agency of refugees (Hamdan 2021) Similarly, examinations of internally displaced persons' mobility within Syria, illustrates the multiple dangers experienced by civilians and the ways in which information is used by armed groups to target specific populations (Lichtenheld and Schon 2021). Additional research on the Syrian conflict examines the Rojava Revolution, through a special issue in the journal Geopolitics. The articles in this special issue draw upon empirically rich research and multiple approaches that highlight the geopolitical specificities of place and space (Hoffmann and Matin, 2021; Shahvisi 2021; Şimşek and Jongerden 2021). Analyses of the Syrian civil war explicate the disparate forms of civilian agency and multiple violences associated with life within a conflict zone and fleeing from that space. Additional research on mobility across space and at borders reveals the institutional structures that cause additional injury to the bodies, lives, and livelihoods of populations seeking refuge.

\section{Borders and mobilities}

The documentation and legal structures that help to form, manage, and control borders and mobility weaponizes economic inability through mobility costs. For example, the cost of passports and visas reveal how desirable movement is linked to neoliberal understandings of value through monetary means, rather than attending to, or valuing vulnerability and one's political or economic need to migrate. Visa costs create barriers that hinder border crossings, as an intentional method and geopolitical tool to control and in some cases prevent passage for particular populations (Recchi et al., 2021). Kreichauf (2021) further explicates the legal spaces of violence by examining asylum laws and the spatial technologies of containment and mobility. Kreichauf (2021) identifies the ways in which "legal-spatial violence" operates to remove legal rights that are generally bestowed upon residents and citizens 
within a territory; and illustrates that the dangers of forced migration do not end but continue once migrants enter a recipient space, that is, Germany and the US.

Other forms of border management highlight power structures associated with control over the means of violence, which produce spatially and temporally multifarious and shifting connections (Buscemi, 2021). Exclusions of individuals through the mechanisms of Mexican deportations from the US exemplify that ways in which exposure to non-state violence via drug cartels in Mexico have become integrated into institutionalized migrant enforcement and deterrence methods in the US (Slack and Martínez, 2021). This is further underscored by Burrell and Schweyer's (2021) research on EU mobility and citizenship. They argue that migrants are caught in a "catch 22 position" where they are marginalized through different mechanisms of categorization that leave low wage-earning migrants both unprotected and devalued within the labor market (8). Other border management methods employ violence to maintain order and security, while in other cases attempts to constrain violence in an effort to create order, have not removed but rather reorganized violence (Schetter and Müller-Koné 2021). This scholarship stresses the complications associated with political and physical vulnerability of mobility as well as the difficult and continually changing maneuvers necessary for refugees and migrants to maintain their lives.

The vulnerability of border crossing for migrants can also lead individuals to engage in extra-legal activities as a survival tactic. The experiences of prolonged vulnerability associated with violence at/ across borders illustrate the overlapping formations of violence and victimizations along with blurring the distinctions between vulnerable migrant and criminalized smuggler (Augustova et al., 2021). This and other analyses expose binary categorizations as a method of institutionalized violence. By removing the complexities of refugee and migrant experiences through everyday practices of racialized segregation that are endemic to borders and border crossings, a simplified representations of the "other" operates through a poisonous politics that criminalizes precarity. Tyerman (2021) examines the "global intimate injustices" of the border through everyday practices in Calais, France to underscore the violence of binary us/them framings that are pervasive among border conceptualizations and management (466). The complexities and multiplicities of situated and mobile refugee life lead individuals toward thorny and restricted choices to ensure survival, which states flatten into narrow categories of vulnerable versus criminal migrant allowing states and other governing bodies to perpetuate an institutionalized violence against refugees through exclusion and incarceration. Drawing from feminist geopolitics, several scholars have centered the body, intimacy, and everyday practices as a method for challenging and critiquing the (mis)management of bodies and borders.

Papada, 2021 draws on feminist geopolitical analyses of the body to examine the EU-Turkey agreement, and "embodied geopolitics of asylum seeking" through the ways in which "mobile bodies" are managed by complicated and contradictory understandings of curative knowledge, vulnerability, and trauma (19). Refugees' experiences of trauma associated with conflict continues to be determined and categorized through singular events and calculations from various refugee resettlement agencies. Ehrkamp et al., 2021 argue that "war does not have a discrete time or space," and that refugee resettlement processes have additional traumatizing effects for migrants (6). For example, the separation of families is both a product of war and the regimes of global refugee resettlement bureaucracies (Ehrkamp et al., 2021). To place a finer point of emphasis "the violence of family separation is not incidental to refugee administration but a symptom of its inscription within colonial practices that have long treated non-White families as sacrificial to the securitization of national territory" (Ehrkamp et al., 2021: 6). Additionally, the growth of anti-immigrant sentiments, populism, and nationalism, includes a reconceptualization of migrants, refugees, and asylum seekers' disparate vulnerabilities by representing them as potential criminals and threats to the sanctity, security, and sovereignty within states of relative security.

\section{Nationalism and populism}

A tried and true method of ensuring exclusionary forms of nationalism - that often manifests through 
segregational politics - continues to rely on a retelling of a nation's past in order to perpetuate fear of a current unknown and unwanted "other." The use of cultural nostalgia through historical narratives that highlight violence and territorial invasion/assault, have been weaponized to produce contemporary discourses of exclusion. For example, the reproduction and repetition of this type of discourse has been used to support the political project of a "closed" Poland to migrants and asylum seekers that are represented as threats to the nation rather than vulnerable subjects in need of refuge (Drozdzewski and Matusz 2021). Similarly, Emmenegger's (2021) analyses of the ways in which reconstructed histories and mythologies of violence of an emergent Somalia nation surrounded by the Ethiopian state, highlights the fragility of sovereign ideologies, which are mitigated through violence. Lizotte (2021) explores the "debt of truth" to illustrate the ways in which conspiracy theories have shaped mainstream politics. He argues that with the abandonment of objective facts this truth debt will be repaid through an increase in catastrophic outcomes associated with climate change, pandemic management, and violence. Griffin and Martin (2021) remind us of the dangers of a single narrative of violent historical events by analyzing race riots through space-time analyses of events that incorporate various and broad analyses of daily live, and multiple materializations of race and nation.

The historization of state violence when simplified clouds popular contemporary understandings a nation's past use of violence. This simplification is then ripe for manipulation for current geopolitical purposes, such as former colonizers shedding their responsibility for mass violence by assigning responsibility for that violence onto colonized other (Mazur 2021). Nethery (2021) also argues that contemporary forms of immigrant incarceration follow similar patters to settler strategies by the British in Australia through the use of administrative detention and categorization of Aboriginal populations into a precarious status as non-citizens, under the auspices of managing perceived threats.

In addition to recreating historical narratives for contemporary geopolitical purposes, states regularly employ legal structures and surveillance technologies as a method to marginalize or remove the rights of indigenous and minority citizens. Spiegel (2021) examines injustices within courtrooms, where indigenous rights activists seek legal methods to avoid harmful toxins; while the legal mechanisms of the Canadian state remain steeped in settler colonial logics that further divest indigenous communities from environmental justice by privileging fossil fuel interests. He further highlights the need for legal geographies to fully engage and center Indigenous epistemologies, laws, and values to improve our understanding of land and resource struggles and the continued violence of settler colonialism (Spiegel 2021). This is echoed by Carter and Warren's (2021) research on corporate interests and economic re-colonialization by denying alternative methods for resolving an issue and not including different forms of knowledge, which ultimately leads to epistemic violence. Analyses of Canada's Indian Act and subsequent exclusive status of Indigenous people, further underscores current legislative action as a reformation of contemporary settler colonialism in Canada (Collis, 2021). In other cases, legal analyses reveal the ways in which gendered cultural stereotypes are operationalized as a geopolitical tool to perpetuate neocolonial, heterosexists, and racist judgments to justify state violence (Klosterkamp 2021). Efforts to push back against the state's various legal (and extra-legal) mechanisms of violent containment or constraints includes various uses of spatial and corporeal methods to ensure safety or resist state incursions against specific populations through racial and other identity-based othering.

\section{Populism and violent exclusions}

The rise of populism within various countries across the globe can be read as a continuation and consistent form of nationalism in both past and present temporalities with marginalized groups as a regular if not consistent target (Nagel and Grove 2021). The special virtual forum on populism in the journal of Political Geography (PG) further explicates the myriad ways in which: nationalism and geopolitics intersect (Kazharski and Makarychev 2021), how "micro-geographies of encounter" challenge national politics (Avni 2021) and how urban spaces are sites of contention and contestation against nationalist 
populism (Yiftachel and Rokem 2021). Focusing on urban spaces, the PG special issue, Urban Badlands, highlights the city as a site for multiple and alternative politics in conjunction with state power and global mobilities. For example, everyday violence extends into global supply chains through urban transport and shipping ports that enable global flows (Jenss 2020). Research on rituals and public religious performance in urban space explicate the ways in which these performative acts help to induce emotions that can contribute to collective violence and riots (Albrecht, 2021). Therefore, public actions for or against the state in urban spaces can and do incorporate violence as a political tactic or resistance method. For example, Gunninga and Smaira's (2021) qualitative inquiry into everyday security occurrences in urban spaces identify assemblages of security/insecurity from both state and non-state actors.

In other cases, non-state intuitions act as an arbiter and spatial counter to state violence, such as exemplified through spatial sanctuary. Research on the orthodox church in Georgia, highlights the use of territoriality to establish the church's power beyond its political linkage to the sovereign state (Merabishvili and Metreveli 2021). Church sanctuary during times of civil conflict, such as the Sri Lankan civil war, is often a fragile space of protection that fosters novel questions about the functionality of sanctuary during conflict and humanitarian crises, which raise new questions about sovereign ontologies (Johnson and Korf 2021). Other challenges to the state occur without the use of violence across scales and through acts of both resistance and refusal to comply.

For example, Tynen (2021) analyzes acts of refusal by the Uyghur population in China, which underscores both the ideological and materials ways in which minority populations work within and outside of state mechanisms of control and management. In other cases state violence continues through various mechanisms of spatial and situational exclusions. State-based necropower in India against subaltern populations occurs through "letting die" exposures to toxic materials and "making die" by way of the state's punitive actions against those advocating for safer living conditions (Kaur, 2021).
These scholars reveal the ways in which states view nonconforming identities or subaltern bodies as an inherent disruptor to state authority and therefore dispensable and dispossessed from state protections. They also underscore the agentic methods people use to navigate their political position and place while they are in the cross-hairs of state pugnacity. The use of state violence against the unwanted other or a state's own citizenry continues to occur under the banner of safety and security, which is limited to the "valued" citizenry and frequently based on antiquated, identity-based dichotomous divisions. Scholars have also revealed the ineffectiveness of violence through rearticulations of peace and security and a careful attention gender, race, and ethnicity within postcolonial contexts (Feghali et al., 2021).

\section{Conclusion}

This report has focused on multiple forms of political violence within and across states, by both state and non-state actors. However, political geographers have also centered peace as an analytical lens through which to understand vulnerability, agency, and security. Although peace studies are compelling and offer important and novel analytical methods, conflict and peace, and corresponding violence and security are interrelated partners in an assemblage of political and economic co-dependence. Peace is not the opposite of violence but rather another method for states to control populations. Peace for one political or social group is regularly contingent upon a state of entrenched or unrelenting physical, institutional or structural violence. Peace is not the opposite of war but a temporal substitute, that engages in violence by other means, that is, non-military, institutional, and structural. Equality, equal access to political participation, and equitable distribution of resources is necessary to ensure security and prevent conflict. Although this romantic notion of social, political and economic ordering is unlikely to occur in any foreseeable future, it can and potentially should remain a goal of progressive politics. Security through direct or indirect violence remains dependent upon categorical divisions. Power through control over the means of both security and violence uses and abuses vulnerability as a mechanism of 
gendered, racialized, and heterosexist hierarchies of value, which are devoid of complexity.

The simplicity of binaries such as us/them framings are foundational to right wing populism, jingoism, and racial extremism, as well as necessary for the dehumanizing process for soldiers to engage in acts of mass-murder during wartime. Giving equal or partial access to resources and political participation, or showing respect for cultural or differential identities is a threat to the geopolitical tool of simplicity. Violence continues to be operationalized as both a fast and acute, or slow and calculated method for state control, neoliberalized privileging of economic value, non-state resistance, and geopolitical action/reaction. However, as Hannah Arendt (1970) argued, violence "can destroy power; it is utterly incapable of creating it."

\section{Declaration of conflicting interests}

The author(s) declared no potential conflicts of interest with respect to the research, authorship, and/or publication of this article.

\section{Funding}

The author(s) received no financial support for the research, authorship, and/or publication of this article.

\section{ORCID iD}

Jennifer Fluri (D) https://orcid.org/0000-0003-4531-6036

\section{References}

Albrecht M (2021) Ritual performances and collective violence in divided cities - The riots in belfast (1886) and Jerusalem (1929). Political Geography 86: 102341.

Arendt H (1970) On violence. Houghton Mifflin Harcourt.

Augustova K., Carrapico H. and Obradović-Wochnik J. (2021) Becoming a smuggler: migration and violence at EU external borders. Geopolitics online ahead of print: 1-22. doi: 10.1080/14650045.2021.1961223.

Avni N (2021) Between exclusionary nationalism and urban citizenship in East Jerusalem/al-Quds. Political Geography 86: 102314.

Baldacchino G (2021) Extra-territorial quarantine in pandemic times. Political Geography 85: 102302.

Bialasiewicz L and Eckes C (2021) 'Individual sovereignty' in pandemic times - A contradiction in terms? Political Geography 85: 102277.
Brigden N and Hallett M (2021) Fieldwork as social transformation: place, time, and power in a violent moment. Geopolitics 26(1): 1-17.

Burrell K and Schweyher M (2021) Borders and bureaucracies of EU mobile citizenship: Polish migrants and the personal identification number in Sweden. Political Geography 87: 102394.

Buscemi F (2021) The art of arms (not) being governed: means of violence and shifting territories in the borderworlds of Myanmar. Geopolitics online ahead of print: 1-28. doi: 10.1080/14650045.2021.1901083.

Carter, D. and Warren, R. (2021) Economic re-colonisation: Financialisation, indigeneity and the epistemic violence of resolution. Political Geography 84(January): 102284.

Collis S. (2021) W(h)ither the Indian Act? How Statutory Law Is Rewriting Canada's Settler Colonial Formation. Annals of the American Association of Geographers online ahead of print: 1-17. doi: 10.1080/ 24694452.2021.1919500.

Drozdzewski D and Matusz P (2021) Operationalising memory and identity politics to influence public opinion of refugees: a snapshot from Poland. Political Geography 86: 102366.

Ehrkamp P, Loyd JM and Secor AJ (2021) Trauma as displacement: observations from refugee resettlement. Annals of the American Association of Geographers online ahead of print: 1-8. doi: 10.1080/ 24694452.2021.1956296.

Emmenegger R (2021) Unsettling sovereignty: violence, myths and the politics of history in the Ethiopian Somali metropolis. Political Geography 90: 102476.

Feghali S, Faria C and Jama F (2021) "Let us create space": reclaiming peace and security in a Kenyan Somali community. Political Geography 90: 102453.

Griffin P and Martin HE (2021) The 1919 'race riots' Within and beyond exceptional moments in South Shields and Glasgow. Political Geography 88: 102408.

Gunning J. and Smaira D. (2021) Who you gonna call? Theorising everyday security practices in urban spaces with multiple security actors-The case of Beirut's Southern Suburbs. Political Geography 102485.

Hamdan A (2021) Ephemeral geopolitics: tracing the role of refugees in Syria's transnational opposition. Political Geography 84: 102299.

Hoffmann C and Matin K (2021) Beyond anarchy and capital? The geopolitics of the Rojava Revolution in Syria. Geopolitics 26(4): 967-972. 
Jenss A (2020) Global flows and everyday violence in urban space: the port-city of Buenaventura, Colombia. Political Geography 77: 102113.

Johnson D and Korf B (2021) The predicament of pastoral sovereignty. Political Geography 87: 102368.

Kaur R (2021) Nuclear necropower: the engineering of death conditions around a nuclear power plant in south India. Political Geography 85: 102315.

Kazharski A and Makarychev A (2021) Belarus, Russia, and the escape from geopolitics. Political Geography 89: 102377 .

Klosterkamp S. (2021) "Security, mobility, and the body Syrian insurgent groups' infrastructures and their geopolitical contestations through/by/in legal institutions". Political Geography 84: 102301.

Kreichauf R (2021) Forced migration and legal-spatial violence in the United States and Germany. Political Geography 87: 102371.

Lichtenheld AG and Schon J (2021) The consequences of internal displacement on civil war violence: evidence from Syria. Political Geography 86: 102346.

Lizotte C (2021) The geography of truth and lies. Political Geography 89: 102410.

Mazur LB (2021) Where the violence happened matters. Geopolitical framing and assessments of collective responsibility for historical violence. Political Geography 85: 102312.

Merabishvili G and Metreveli T (2021) Spiritual geopolitics of Georgia's territorial integrity. Political Geography 87: 102374.

Mitropoulos A (2021) The pandemic, and the pandemonium of European philosophy. Political Geography 84: 102275.

Nagel C and Grove K (2021) Virtual forum introduction: populist nationalisms and new geographies of exclusion. Political Geography 89: 102429.

Nethery A (2021) Incarceration, classification and control: administrative detention in settler colonial Australia. Political Geography 89: 102457.
Papada E (2021) Engaging the geopolitics of asylum seeking: the care/control function of vulnerability assessments in the context of the EU-Turkey agreement. Geopolitics online ahead of print: 1-25. doi: 10 . 1080/14650045.2021.1884548.

Recchi E, Deutschmann E, Gabrielli L, et al. (2021) The global visa cost divide: how and why the price for travel permits varies worldwide. Political Geography 86: 102350 .

Schetter C and Müller-Koné M (2021) Frontiers' violence: the interplay of state of exception, frontier habitus, and organized violence. Political Geography 87: 102370.

Shahvisi A (2021) Beyond orientalism: exploring the distinctive feminism of democratic confederalism in Rojava. Geopolitics 26(4): 998-1022.

Simpson M (2021) For a prefigurative pandemic politics: disrupting the racial colonial quarantine. Political Geography 84: 102274.

Şimşek B and Jongerden J (2021) Gender revolution in Rojava: the voices beyond tabloid geopolitics. Geopolitics 26(4): 1023-1045.

Slack J and Martínez DE (2021) Postremoval geographies: immigration enforcement and organized crime on the U.S.-Mexico border. Annals of the American Association of Geographers 111(4): 1062-1078.

Spiegel SJ (2021) Climate injustice, criminalisation of land protection and anti-colonial solidarity: courtroom ethnography in an age of fossil fuel violence. Political Geography 84: 102298.

Tyerman T (2021) Everyday borders in Calais: the globally intimate injustices of segregation. Geopolitics 26(2): 464-485.

Tynen S (2021) "Keep withstanding": territory in the body, home and market in Xinjiang, China. Political Geography 84: 102310.

Yiftachel O and Rokem J (2021) Polarizations, exclusionary neonationalisms and the city. Political Geography 86: 102329. 